University of Nebraska - Lincoln

DigitalCommons@University of Nebraska - Lincoln

No-Choice Preference of Cerotoma trifurcata (Coleoptera:

Chrysomelidae) to Potential Host Plants of Bean Pod Mottle Virus (Comoviridae) in lowa

\author{
Jeffrey Bradshaw \\ University of Nebraska-Lincoln, jbradshaw2@unl.edu \\ Marlin E. Rice \\ lowa State University, marlinrice@gmail.com \\ John H. Hill \\ lowa State University, johnhill@iastate.edu
}

Follow this and additional works at: https://digitalcommons.unl.edu/panhandleresext

Part of the Agriculture Commons

Bradshaw, Jeffrey; Rice, Marlin E.; and Hill, John H., "No-Choice Preference of Cerotoma trifurcata (Coleoptera: Chrysomelidae) to Potential Host Plants of Bean Pod Mottle Virus (Comoviridae) in lowa" (2007). Panhandle Research and Extension Center. 39.

https://digitalcommons.unl.edu/panhandleresext/39

This Article is brought to you for free and open access by the Agricultural Research Division of IANR at DigitalCommons@University of Nebraska - Lincoln. It has been accepted for inclusion in Panhandle Research and Extension Center by an authorized administrator of DigitalCommons@University of Nebraska - Lincoln. 


\title{
No-Choice Preference of Cerotoma trifurcata (Coleoptera: Chrysomelidae) to Potential Host Plants of Bean Pod Mottle Virus (Comoviridae) in Iowa
}

\author{
JEFFREY D. BRADSHAW, ${ }^{1,2}$ MARLIN E. RICE, ${ }^{1}$ AND JOHN H. HILL ${ }^{3}$
}

\begin{abstract}
J. Econ. Entomol. 100(3): 808-814 (2007)
ABSTRACT To better understand the naturally occurring host range of Bean pod mottle virus (family Comoviridae, genus Comovirus, BPMV) and its principal vector Cerotoma trifurcata (Förster) (Coleoptera: Chrysomelidae), 18 field-collected perennial plant species were tested for the presence of BPMV. By using no-choice assays, we determined the preference of these plants by bean leaf beetle, by measuring their level of herbivory relative to soybean, Glycine max (L.). New food hosts for adult bean leaf beetles include Lespedeza capitata (Michaux), Lotus corniculatus L., Trifolium alexandrinum L., Trifolium ambiguum Bieberstein, and Trifolium incarnatum L. Desmodium illinoense Gray is discovered as a new naturally occurring host for BPMV.
\end{abstract}

KEY WORDS enzyme-linked immunosorbent assay, Fabaceae, insect herbivory, leaf area measurement, reverse transcription-polymerase chain reaction

The bean leaf beetle, Cerotoma trifurcata (Förster) (Coleoptera: Chrysomelidae), is endemic to North America and a long-known pest of peas (Vigna spp.) (McConnell 1915); beans (Phaseolus spp.) (Chittenden 1891, Eddy and Nettles 1930, Aguyoh et al. 2004); and soybean, Glycine max (L.) (Eddy and Nettles 1930, Higley and Boethel 1994). The recent need to understand the population dynamics (Lam et al. 2001, Carrillo et al. 2005) and management (Lam et al. 2002; Krell et al. 2004, 2005; Koch et al. 2005) of the bean leaf beetle is probably a response to dramatic increases in its abundance (Bradshaw and Rice 2003, Krell et al. 2003). This abundance is positively correlated to Bean pod mottle virus (family Comoviridae, genus Comovirus, BPMV) incidence in soybean (Hopkins and Mueller 1984); therefore, large vector populations have probably contributed to an apparent increase in this virus in the north central United States (Bradshaw and Rice 2003).

BPMV, discovered in 1947 (Zaumeyer and Thomas 1948), is a common pathogen of soybean in the Americas (Milbrath et al. 1975, Pitre et al. 1979, Hopkins and Mueller 1983, Lin and Hill 1983, Ghabrial et al. 1990, Fribourg and Perez 1994, Michelutti et al. 2002, Anjos et al. 1999, Sikora and Murphy 2005). It is of serious concern for soybean seed production in the United States (Giesler et al. 2002). This viral disease results in yield and quality losses in soybean (Quiniones et al. 1971, Horn et al. 1973, Myhre et al. 1973, Hopkins and

\footnotetext{
${ }^{1}$ Department of Entomology, Iowa State University, Ames IA 50011.

${ }^{2}$ Corresponding author, e-mail: bradshaw@iastate.edu.

${ }^{3}$ Department of Plant Pathology, Iowa State University, Ames IA 50011
}

Mueller 1984, Ragsdale 1984, Giesler et al. 2002, Krell et al. 2003); however, "field tolerance" has been reported recently (Hill et al. 2007).

Although the principal vector of BPMV is the bean leaf beetle (Mueller and Haddox 1980), there are other coleopterous vectors within the Chrysomelidae (Horn et al. 1970, Mabry et al. 2003, Werner et al. 2003), Meloidae (Patel and Pitre 1971), and Coccinellidae (Fulton and Scott 1974); however, the susceptible host range of BPMV, by mechanical inoculation, includes plants in the families Apocynaceae, Chenopodiaceae, and Fabaceae (=Leguminosae) (Caesalpinioideae and Papilionoideae). Nonsusceptible plant hosts include species of Compositae, Cruciferae, Cucurbitaceae, Solanaceae, and Fabaceae (Papilionoideae) (Brunt et al. 1996). Although vector transmission has been demonstrated from Desmodium paniculatum (L.) to soybean via bean leaf beetles (Waldbauer and Kogan 1976), the range of possible naturally occurring hosts susceptible to both vector and virus is still unknown. This information could be central to the determination of the primary inoculum source of BPMV.

Krell et al. (2003), upon examination of potential primary inoculum sources, estimated a low frequency of BPMV transmission from seed and overwintered bean leaf beetles of 0.037 and $1.6 \%$, respectively. Additionally, of 23 field-collected plant species tested, only Desmodium canadense (L.) was positive for BPMV. Perennial host plants are thought to be an important source for BPMV (Moore et al. 1969, Horn et al. 1970, Stace-Smith 1981, Krell et al. 2003), possibly because of the opportunity for the virus to overwinter within the plant. However, in Iowa, distribution of this 
host plant does not fully explain the temporal appearance and ultimate impact of the disease (Krell et al. 2004).

There is a lack of intensive, replicated sampling for most potential host species for BPMV. Furthermore, bean leaf beetle feeding has been observed on some BPMV hosts (Krell et al. 2003), and host preference has been shown for some Fabaceae (Henn 1989); however, the acceptability of most perennial legumes to bean leaf beetles has not been determined. Therefore, the objective of this study was to investigate the potential host range overlap between the bean leaf beetle and presence of BPMV in nature.

\section{Materials and Methods}

Bean Leaf Beetle No-Choice Preference Assays. Female bean leaf beetles, determined by their large size and darkened frons (Kogan et al. 1980, Sims et al. 1984), were field-collected from Medicago sativa L. by using a 20-cm sweep net in May 2004 and 2005. They were held in groups of three in 9-cm petri dishes for $48 \mathrm{~h}$ (maintained at $24^{\circ} \mathrm{C}$ under a photoperiod of $16: 8$ [L:D] h) without access to food or water to cull out weak beetles, to ensure that beetles had similar levels of hunger, and to allow beetles to acclimatize to test conditions.

After acclimatization, beetles (three beetles per petri dish) were given access to one leaflet (with the dish lid and bottom sealed together with electrical tape to prevent moisture loss) from one of the following fabacious species in 2004 (10 plants of each species were collected the day of the experiment, and six of the 10 plants were assayed): Amorpha canescens Pursh; Astragalus cicer L.; G. max 'Mark RR'; Lotus corniculatus L.; M. sativa; Melilotus officinalis (L.), white sweet clover; Melilotus officinalis, yellow sweet clover; Petalostemum purpureum (F.); Robinia pseudoacacia L.; Securigera varia (L.); Trifolium ambiguum Bieberstein; Trifolium hybridum L.; Trifolium pratense L.; and Trifolium repens L. In 2005, the following hosts were used ( 10 plants of each species were collected and three of the 10 plants were assayed): A. canescens, G. max Mark RR, L. corniculatus, M. officinalis, R. pseudoacacia, Trifolium alexandrinum L., T. ambiguum, Trifolium incarnatum (F.), and T. pratense. Dishes were maintained at $24^{\circ} \mathrm{C}$ under a photoperiod of 16:8 (L:D) h for $24 \mathrm{~h}$ (in 2004) or $48 \mathrm{~h}$ (in 2005), after which leaflets were removed and pressed until dry. All plants were collected from the Field Extension Education Laboratory, Iowa State University (Boone Co., IA), except for R. pseudoacacia (collected from McHose Park, also in Boone Co.).

These plant species were chosen because they are perennials, their vegetative growth overlapped with the emergence of overwintered C. trifurcata populations (i.e., they potentially could be primary inoculum sources for BPMV), and they were available free of pesticides. Beetle abundance was limiting to this study during 2004 and 2005; therefore, more plants were collected than assayed. However, all 10 plants were retained for virus assays.
In 2006, bean leaf beetles were collected at a prairie near Ames, IA (42 $\left.07^{\prime} 48^{\prime \prime} \mathrm{N}, 093^{\circ} 33^{\prime} 32^{\prime \prime} \mathrm{W}\right)$. Two legumes dominated this location, Desmodium illinoense Gray and Lespedeza capitata Michaux; they had heretofore not been reported as hosts for C. trifurcata or BPMV; however, both had visual evidence of bean leaf beetle injury. Ten plant samples (a nearly complete census from this locality) of both species (one leaflet each) were collected and tested using the conditions described above, except one bean leaf beetle was used per dish and the feeding period was $60 \mathrm{~h}$. For comparison, 10 G. max 'Williams' leaflets (grown under glasshouse conditions) were included in this experiment as a control.

Leaflet Area Measurement. Leaflet images were captured with a digital scanner (Hewlett-Packard Scanjet 4670, Hewlett-Packard Co., Houston, TX) in black and white (i.e., 1 bit/pixel) at 286.12 pixels $/ \mathrm{cm}$, uploaded to a computer (Dell OptiPlex GX150 with a Pentium 6 processor, Dell USA, Austin, TX), and saved as an uncompressed TIF by using Adobe Photoshop 7.0.1 (Adobe Systems, San Jose, CA). We previously determined that the measurement of two-dimensional objects acquired at 286.12 pixels/ $\mathrm{cm}$ is not adversely affected by variations in shape or size (unpublished data). For each image, the "Histogram" function in Adobe Photoshop was used to count pixels. For more intuitive comparisons, digitally scanned areas (in pixels) were converted to square centimeters by dividing the number of black pixels into the number of total square pixels per millimeter in the images as determined by Photoshop as follows:

$$
\text { Area }\left(\mathrm{mm}^{2}\right)=\text { black pixels } /(\text { total pixels } / \mathrm{mm})^{2}
$$

For 2006 experiments, area measurements were taken as described above, except by capturing leaflet images in 16-bit color. Injured areas were selected with the "magic wand tool" or "color selection tool," because the skeletonization of the $D$. illinoense leaflets was such that a very close-knit leaflet skeleton remained in injured areas, which was not accurately captured as a 1-bit image. The area of the selected area was determined using the image histogram as described above.

BPMV Host Assays. Ten samples each of the aforementioned field-collected plants were tested for presence of BPMV by enzyme-linked immunosorbent assay (ELISA), Western blot assay, and polymerase chain reaction (PCR). For ELISA and Western blot, samples were taken from the same plants used for the no-choice beetle assay, extracted in 0.05 M phosphate-buffered saline with $0.05 \%$ Tween 20 (PBST), pH 7.2, and held at $-20^{\circ} \mathrm{C}$. Samples of plant species (except $D$. illinoense and L. capitata) were combined and concentrated using 2-ml filtration devices with a 30,000-mol. wt. filter (Millipore Corporation, Billerica, MA) and centrifuged at $4,500 \times g$ for $1 \mathrm{~h}$. The ELISA and Western blot procedures were similar to those used by Krell et al. (2003). D. illinoense and L. capitata were extracted in PBST, $\mathrm{pH} 7.2$, containing $2 \%$ polyvinylpolypyrrolidone (PVPP) and $1 \%$ sodium hydrosulfite. The later extraction buffer was 
Table 1. Fabaceae tested by no-choice assay for herbivory and acceptability by adult $C$. trifurcata

\begin{tabular}{|c|c|c|c|c|c|c|c|}
\hline \multirow{2}{*}{$\begin{array}{l}\text { Yr of exp } \\
\text { (duration) }\end{array}$} & \multirow[t]{2}{*}{ Species } & \multirow[t]{2}{*}{ Common name } & \multirow{2}{*}{$\begin{array}{l}\text { Mean area } \\
\text { consumed } \\
\left(\mathrm{mm}^{2}\right)^{a}\end{array}$} & \multicolumn{2}{|c|}{$\begin{array}{c}\text { Confidence } \\
\text { interval }(95 \%)\end{array}$} & \multirow{2}{*}{$P$ value } & \multirow{2}{*}{$\begin{array}{c}\text { Fraction of } \\
\text { leaflets } \\
\text { with } \\
\text { herbivory }\end{array}$} \\
\hline & & & & Lower & Upper & & \\
\hline \multirow[t]{14}{*}{$2004(24 \mathrm{~h})$} & Amorpha canescens Pursh & Lead plant & 0.12 & -0.07 & 0.09 & \multirow[t]{14}{*}{0.0002} & $1 / 6$ \\
\hline & Astragalus cicer $\mathrm{L}$. & Cicer milkvetch & 0.00 & -0.08 & 0.08 & & $0 / 6$ \\
\hline & Glycine $\max (\mathrm{L})$. & Soybean (Mark RR) & 2.29 & 0.15 & 0.31 & & $6 / 6$ \\
\hline & Lotus corniculatus L. & Birdsfoot trefoil & $<0.01$ & -0.08 & 0.08 & & $1 / 6$ \\
\hline & Melilotus officinalis (L.) & Yellow sweet clover & 0.00 & -0.08 & 0.08 & & $0 / 6$ \\
\hline & Medicago sativa $\mathrm{L}$. & Alfalfa & $<0.01$ & -0.08 & 0.08 & & $1 / 6$ \\
\hline & Medicago officinalis (L.) & White sweet clover & 0.16 & -0.06 & 0.10 & & $1 / 6$ \\
\hline & Petalostemum purpureum (F.) & Purple prairie clover & 0.00 & -0.08 & 0.08 & & $0 / 6$ \\
\hline & See corrected Table & following na & 14 & -0.08 & 0.08 & & $1 / 6$ \\
\hline & & & & -0.08 & 0.08 & & $1 / 6$ \\
\hline & & & & -0.08 & 0.08 & & $1 / 6$ \\
\hline & Trifolium pratense $\mathrm{L}$. & Red clover & 0.07 & -0.07 & 0.09 & & $3 / 6$ \\
\hline & Trifolium repens $\mathrm{L}$. & White clover & $<0.01$ & -0.06 & 0.10 & & $4 / 6$ \\
\hline & Trifolium ambiguum Bieberstein & Kura clover & 2.07 & 0.13 & 0.29 & & $3 / 6$ \\
\hline \multirow[t]{9}{*}{$2005(48 \mathrm{~h})$} & Amorpha canescens Pursh & Lead plant & 0.01 & -0.52 & 0.52 & \multirow[t]{9}{*}{0.0278} & $1 / 3$ \\
\hline & Glycine $\max (\mathrm{L})$. & Soybean (Mark RR) & 13.44 & 0.82 & 1.86 & & $3 / 3$ \\
\hline & Lotus corniculatus $\mathrm{L}$. & Birdsfoot trefoil & 1.57 & -0.36 & 0.68 & & $2 / 3$ \\
\hline & Melilotus officinalis (L.) & White sweet clover & 0.02 & -0.52 & 0.52 & & $1 / 3$ \\
\hline & Robinia pseudoacacia L. & Black locust & 0.52 & -0.47 & 0.57 & & $2 / 3$ \\
\hline & Trifolium alexandrinum L. & Berseem clover & 0.21 & -0.50 & 0.54 & & $3 / 3$ \\
\hline & Trifolium ambiguum Bieberstein & Kura clover & 2.20 & -0.30 & 0.74 & & $3 / 3$ \\
\hline & Trifolium incarnatum (F.) & Crimson clover & 1.21 & -0.40 & 0.64 & & $3 / 3$ \\
\hline & Trifolium pratense $\mathrm{L}$. & Red clover & 0.69 & -0.45 & 0.59 & & $2 / 3$ \\
\hline \multirow[t]{3}{*}{$2006(60 \mathrm{~h})$} & Desmodium illinoense (L.) & Illinois ticktrefoil & 1.34 & -0.13 & 0.40 & \multirow[t]{3}{*}{0.0001} & $10 / 10$ \\
\hline & Glycine $\max (\mathrm{L})$. & Soybean (Williams) & 9.42 & 0.67 & 1.21 & & $9 / 10$ \\
\hline & Lespedeza capitata (Michaux) & Roundhead lespedeza & 0.15 & -0.25 & 0.28 & & $3 / 10$ \\
\hline
\end{tabular}

found to eliminate false positives (by ELISA) for many legumes (J.D.B., unpublished data) and simplified the search for BPMV hosts by ELISA.

To further exclude the possibility of a false positive, total RNA was extracted from immunopositive plants and tested by reverse-transcription (RT)-PCR. Plant samples from immunopositive plants were collected into liquid $\mathrm{N}_{2}$ and stored at $-80^{\circ} \mathrm{C}$. To extract total RNA, $\approx 100 \mu \mathrm{g}$ of frozen plant tissue was added to $1 \mathrm{ml}$ of TRIzol (Invitrogen, Carlsbad, CA), vortexed for 15 $\mathrm{min}$ at room temperature, and then $300 \mu \mathrm{l}$ of chloroform was added, and the sample was vortexed for 10 $\min$. Samples were centrifuged at $3,900 \times g$ at $4^{\circ} \mathrm{C}$ for $10 \mathrm{~min}$, and the supernatant was extracted twice more with chloroform. The RNA was precipitated from the supernatant by addition of an equal volume of cold $\left(-20^{\circ} \mathrm{C}\right)$, ribonuclease-free $70 \%$ isopropanol followed by incubation for $30 \mathrm{~min}$ at room temperature. The preparation was centrifuged at $18,320 \times g$ at $4^{\circ} \mathrm{C}$ to recover the pellet, which was washed using $300 \mu \mathrm{l}$ of cold $\left(-20^{\circ} \mathrm{C}\right)$, ribonuclease-free $70 \%$ ethanol. The pellet was air-dried for $\approx 5 \mathrm{~min}$ and suspended in ribonuclease-free distilled water.

Reverse transcription and PCR protocols were followed according to Takara, version 3.0 (Takara Bio Inc., Otsu, Japan), by using random 9-mers for reverse transcription primers and BPMV, RNAl-specific forward ( $3^{\prime}$-TGTGCTACCATTGCAGTTTCTA-5') and reverse (3'-AAGTTTGGTCTACAACATAATGA-5') PCR primers. Avian myeloblastosis virus reverse transcriptase was used for RNA transcription, and Ex Taq-HS (Takara Bio Inc.) was used as a DNA poly- merase for PCR. The dNTPs for the PCR are supplied in this Takara kit as a separate reagent. Conditions for reverse transcription were $30^{\circ} \mathrm{C}(10 \mathrm{~min}), 42^{\circ} \mathrm{C}(60$ $\min ), 94^{\circ} \mathrm{C}(5 \mathrm{~min})$, and $4^{\circ} \mathrm{C}$ (hold) and for PCR were $94^{\circ} \mathrm{C}(2 \mathrm{~min}), 32$ cycles $\left[94^{\circ} \mathrm{C}(30 \mathrm{~s}), 52^{\circ} \mathrm{C}(30 \mathrm{~s}), 68^{\circ} \mathrm{C}\right.$ $(5 \mathrm{~min})], 68^{\circ} \mathrm{C}(15 \mathrm{~min})$, and $8^{\circ} \mathrm{C}$ (hold) by using a MiniCycler thermocycler (MJ Research, Watertown, MA).

Data Analysis. Data were analyzed using the mixed model procedure in SAS (PROC MIXED, SAS Institute 2003). For leaflet area consumed, analysis of variance (ANOVA) was used to determine differences between host plant herbivory. Estimates were considered statistically significant if the $P$ value was $<0.05$, and comparisons were different where their $95 \%$ confidence interval for the estimate did not overlap.

\section{Results and Discussion}

Bean Leaf Beetle Food Host Assays. Two issues were considered in assessment of bean leaf beetle herbivory. First, the likely host range on perennial legumes, and second, a comparison of herbivory on potential hosts plants with that on soybean. To assess the first issue, the number of leaflets with any feeding was counted and if greater than one, the plant species was assumed to be a likely host (i.e., an acceptable host). To assess the second issue, estimates of leaflet area consumed were compared with soybean to indicate a degree of preference relative to soybean.

The following perennial plants were determined as acceptable hosts for adult bean leaf beetle in Iowa: $D$. 
Table 2. Food plants of adult C. trifurcata

\begin{tabular}{|c|c|c|c|}
\hline Family & Scientific name $\mathrm{a}^{a, b}$ & Common name $(\mathrm{s})^{a, b}$ & Reference \\
\hline \multirow[t]{27}{*}{ Fabaceae } & Amphicarpaea bracteata (L.) & American hogpeanut & Chittenden 1897 \\
\hline & Desmodium canadense (L.) & Sowy ticktrefoil & Krell et al. 2003 \\
\hline & Desmodium canescens (L.) & Hary ticktrefoil & McConnell 1915 \\
\hline & $\begin{array}{l}\text { Desmodium cuspidatum (Muhlenberg } \\
\text { ex Willdenow) }\end{array}$ & Lrgebract ticktrefoil & $\begin{array}{l}\text { Waldbauer and } \\
\text { Kogan } 1976^{c}\end{array}$ \\
\hline & Desmodium illinoense Gray & Illinois ticktrefoil & $\begin{array}{l}\text { Waldbauer and } \\
\text { Kogan } 1976^{c d}\end{array}$ \\
\hline & Desmodium laevigatum (Nuttall) & Smooth ticktrefoil & Chittenden 1897 \\
\hline & Desmodium paniculatum (L.) & Panicledleaf ticktrefoil & Moore et al. 1969 \\
\hline & Desmodium tortuosum (Swartz) & Dixie ticktrefoil & $\begin{array}{l}\text { Chittenden 1898, } \\
\text { Eddy and } \\
\text { Nettles } 1930\end{array}$ \\
\hline & Glycine $\max (\mathrm{L})$. & Soybean & McConnell 1915 \\
\hline & Lespedeza capitata (Michaux) & Roundhead lespedeza & $-^{d}$ \\
\hline & Lespedeza spp. & & Chittenden 1891 \\
\hline & Lotus corniculatus $\mathrm{L}$. & Birdsfoot trefoil & $-^{d}$ \\
\hline & Phaseolus lunatus $\mathrm{L}$. & Sieva bean & Henn 1989 \\
\hline & Phaseolus vulgaris $\mathrm{L}$. & Kidney bean & Chittenden 1897 \\
\hline & Robinia pseudoacacia $\mathrm{L}$. & Black locust & Chittenden $1897^{d}$ \\
\hline & Strophostyles helvola (L.) & Amberique-bean & $\begin{array}{l}\text { Waldbauer and } \\
\text { Kogan } 1976^{c}\end{array}$ \\
\hline & Trifolium alexandrinum $\mathrm{L}$. & Egyptian clover & $-^{d}$ \\
\hline & Trifolium ambiguum Bieberstein & Kura clover & $-^{d}$ \\
\hline & Trifolium pratense $\mathrm{L}$. & Red clover & Davis $1950^{d}$ \\
\hline & Trifolium incarnatum $\mathrm{L}$. & Crimson clover & $-d$ \\
\hline & Trifolium repens $\mathrm{L}$. & White clover & Henn 1989 \\
\hline & Vigna aconitifolia (Jacquin) & Moth bean & McConnell 1915 \\
\hline & Vigna angularis (Wildenow) & Adzuki bean & Henn 1989 \\
\hline & Vigna radiata $(\mathrm{L})$. & Mung bean & Henn 1989 \\
\hline & Vigna unguiculata $(\mathrm{L})$. & Blackeyed pea & Henn 1989 \\
\hline & Vigna u. sesquipedalis (L.) & Yardlong bean & Henn 1989 \\
\hline & Wisteria floribunda (Wildenow) & Japanese wisteria & Staines 1986 \\
\hline Celastraceae & Euonymus atropurpureus Jacquin & Burningbush & Helm et al. 1983 \\
\hline \multirow[t]{2}{*}{ Urticaceae } & Urtica dioica $\mathrm{L}$. & Stinging nettle & Helm et al. 1983 \\
\hline & Laportea canadensis $(\mathrm{L})$. & Canadian woodnettle & Helm et al. 1983 \\
\hline \multirow[t]{2}{*}{ Cucurbitaceae } & Cucurbita pepo $\mathrm{L}^{e}$ & $\begin{array}{l}\text { (i.e., pumpkin 'Magic lantern' and } \\
\text { squash 'Turk's turbin') }\end{array}$ & Koch et al. 2004 \\
\hline & Cucumis sativus $\mathrm{L}^{e}$ & Garden cucumber & Koch et al. 2004 \\
\hline Poaceae & Zea mays $\mathrm{L}$. & Corn & $\begin{array}{l}\text { Metcalf and } \\
\text { Metcalf } 1993\end{array}$ \\
\hline
\end{tabular}

${ }^{a}$ Scientific and common names taken from the PLANTS database (USDA 2006).

${ }^{b}$ Plant species are listed as food plants where direct herbivory is reportedly observed or where eggs are found near the plant.

${ }^{c}$ Indirect evidence- host plant evidence based on the presence of eggs.

${ }^{d}$ This record is reported first or confirmed in this manuscript.

${ }^{e}$ Only the cucurbit varieties and common names were provided by Koch et al. (2004). C. pepo and C. sativus are inferred for pumpkin and squash, respectively.

illinoense, L. corniculatus (new host), R. pseudoacacia, T. alexandrinum (new host), T. ambiguum (new host), T. incarnatum (new host), T. pretense, T. repense, and L. capitata (new host) (Table 1). Additionally, for $L$. capitata, T. ambiguum, and D. illinoense, one of us (J.D.B.) has observed and found evidence of bean leaf beetle feeding on leaflets of these plants in nature during May and June.

Overall, soybean was the most acceptable host plant in this study, i.e., had the greatest proportion of leaflets with herbivory (Table 1). Additionally, compared with soybean, most perennial hosts support significantly less herbivory (Table 1 ). However, because of leaflet thickness, the area of herbivory on $D$. illinoense may represent an underestimate. Natural host plants of the bean leaf beetle (e.g., L. capitata and D. illinoense) received significantly less herbivory than soybean (Table 1, 2006 experiment). Herbivory on T. ambiguum was significantly less in $48 \mathrm{~h}$ of exposure than that on soybean, but it was not significantly less within $24 \mathrm{~h}$ (Table 1, 2004 and 2005 experiment). This finding indicates that the rate of herbivory may differ between hosts; however, there were half the number of replicates in 2005 as in 2004. Every test plant received some feeding. However, some plants received $<0.01 \mathrm{~mm}^{2}$ of herbivory in $24 \mathrm{~h}$, which is well within the random error for the scanner used in this study, $\pm 0.06 \mathrm{~mm}^{2}$ (unpublished data). Therefore, pairwise comparisons for herbivory $\leq 0.06 \mathrm{~mm}^{2}$ are not meaningful. In the final assay, both D. illinoense and L. capitata received significantly less feeding than soybean (Table 2, 2006 experiment). However, D. illinoense received more feeding than L. capitata.

Some species (e.g., T. repens) received an average herbivory of $<0.01 \mathrm{~mm}^{2}$ with more than half of the leaflets receiving some herbivory (Table 1, 2004 experiment). Although leaflets in this experiment ap- 


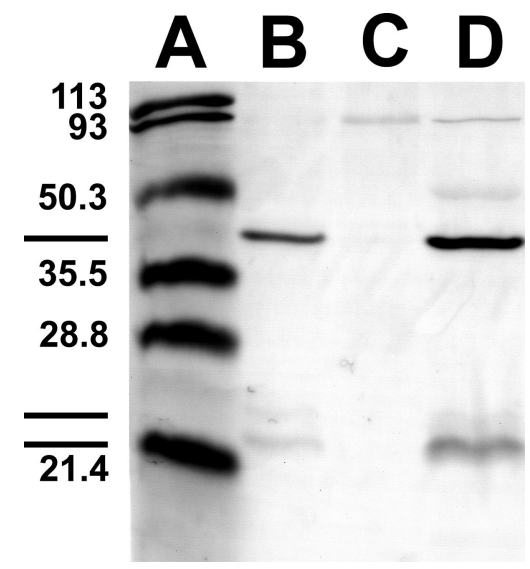

Fig. 1. Western blot for the detection of BPMV in $D$. illinoense. (A) Protein marker, units in molecular mass (kilodaltons). (B) BPMV-infected soybean (Williams) sap. (C) Noninfected soybean (Williams) sap. (D) BPMV-infected $D$. illinoense from total protein extraction. Solid bars to the left of image indicate expected position for the three bands associated with BPMV coat protein: large protein, $41 \mathrm{kDa}$ and small protein, $\approx 22 \mathrm{kDa}$ (consisting of two migration forms).

parently did not differ greatly in observed thickness (unpublished data), physical factors can mediate $C$. trifurcata preference, e.g., trichome density (Lam and Pedigo 2001). The involvement of chemical host factors in C. trifurcata host preference has not been studied.

BPMV Host Assay. Of all the tested plants, only $D$. illinoense was positive for BPMV by ELISA, Western blot (Fig. 1), and RT-PCR (Fig. 2). On a Western blot, sap extracted from $D$. illinoense gave bands that corresponded to the large and small coat protein subunits of BPMV and corresponded to similar bands in a BPMV-infected soybean plant. Additionally, of the $10 \mathrm{D}$. illinoense tested, all 10 plants were positive for BPMV. Furthermore, RT-PCR of the total RNA from $D$. illinoense leaflets yielded the

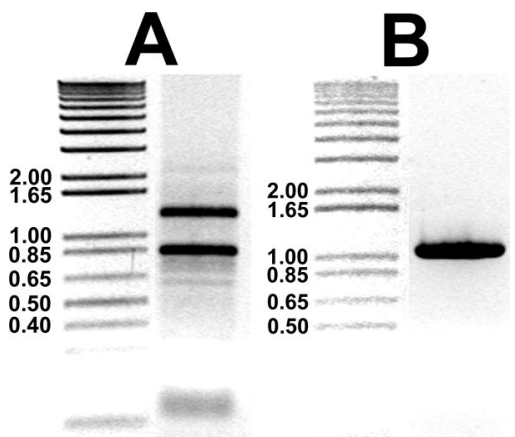

Fig. 2. Total extracted RNA (A, marker, left lane in kilobases [kb]; sample, right lane) and cDNA from RT-PCR of BPMV RNA1 (using a primer pair with an expected product size of $1.037 \mathrm{~kb}$ ) from $D$. illinoense ( $\mathrm{B}$, marker, left lane [kb]; sample, right lane) in ethidium bromide-stained agarose gel. expected product size for an RNAl cDNA-specific primer pair (Fig. 2B). This is the first report of BPMV from D. illinoense.

Many plants (e.g., A. canescens, T. pratense, and R. pseudoacacia) yielded false positives by ELISA, as was similarly noted by Krell et al. (2003), via PBST sap extraction. However, sap extracted from $R$. pseudoacacia (used as a false-positive control in this test), D. illinoense, and L. capitata, using PBST containing PVPP and sodium hydrosulfite, resulted in no false positives compared with sap extracted in PBST alone. Similar results have been noted when extracting sap from various legumes (unpublished data).

The bean leaf beetle may have a broader host range (Table 2) than the natural host range for BPMV. Searches for the natural reservoir for this virus have often found Desmodium spp. as an important source for this virus (Moore et al. 1969, Walters and Lee 1969, Lee and Walters 1970, Krell et al. 2003). Of the plant species listed on the Virus Identification Data Exchange database (Brunt et al. 1996 ) as hosts of BPMV, $\approx 16$ species are susceptible and 21 species are nonsusceptible; however, these conclusions are based primarily on mechanical inoculations. Species such as T. incarnatum are listed as susceptible hosts, whereas T. pratense and T. rapens are nonsusceptible. In this study, BPMV was not found to occur naturally in any of these hosts. If BPMV requires the activity of certain ribonucleases for efficient transmission (Gergerich et al. 1986; Gergerich and Scott 1988a, 1988b), and if some legumes contain factors that inhibit ribonuclease activity, there may be a discontinuity between the natural host range of BPMV by mechanical inoculation and that by beetle transmission.

Plants such as T. ambiguum and L. capitata were negative for BPMV, even though bean leaf beetle herbivory and many beetles were found on these plants. If such plants truly represent nonsusceptible hosts for BPMV, it may be possible that bean leaf beetles "clean" themselves of virus in nature. Furthermore, such BPMV nonhosts could be used as a trap crop for both virus and bean leaf beetles.

Sixteen species of Desmodium are found in Iowa (USDA 2006), and, of these species, three species are now known to be susceptible to BPMV in nature (Moore et al. 1969, Krell et al. 2003). Other Desmodium spp. should be assayed to determine the wild host range of this virus. The distribution and abundance of these hosts are not well known in Iowa; however, this knowledge may be helpful in understanding BPMV epidemics. Furthermore, simply identifying a susceptible host plant is insufficient to determine its potential impact on the pathosystem. BPMV exists as more than one subgroup population in nature ( $\mathrm{Gu}$ et al. 2002) that is associated with varying degrees of symptom severity. The Desmodium BPMV isolate found in this study is currently being characterized. 


\section{Acknowledgments}

We thank R. O. Pope for assistance in locating and identifying plants used in this study and A. L. Eggenberger and C. Zhang for insight and suggestions concerning molecular methods. This research was funded in part by the Iowa Soybean Association and the North Central Soybean Research Program. This journal paper of the Iowa Agriculture and Home Economics Experiment Station, Ames, IA, Project No. 3608, was supported, in part, by Hatch Act and State of Iowa funds.

\section{References Cited}

Aguyoh, J. N., J. B. Masiunas, and C. Eastman. 2004. Interaction of insects and weeds in a snap bean agroecosystem. HortScience 39: 287-290.

Anjos, J.R.N., P.S.T. Brioso, and M.J.A. Charchar. 1999. Partial characterization of bean pod mottle virus in soybeans in Brazil. Fitopatol. Bras. 24: 85-87.

Bradshaw, J. D., and M. E. Rice. 2003. Bean leaf beetle: a current and historical perspective. Integrated Crop Management newsletter, IC-429(3): 20-21. Iowa State University, Ames, IA.

Brunt, A. A., K. Crabtree, M. J. Dallwitz, A. J. Gibbs, L. Watson, and E. J. Zurcher [eds.]. 1996. Plant viruses online: descriptions and lists from the VIDE database. (http:/ / biology. anu.edu.au/Groups/MES/vide/) (1996 onward).

Carrillo, M. A., R. L. Koch, E. C. Burkness, K. Bennett, D. W. Ragsdale, and W. D. Hutchison. 2005. Supercooling point of bean leaf beetle (Coleoptera: Chrysomelidae) in Minnesota and a revised predictive model for survival at low temperatures. Environ. Entomol. 34: 1395-1401.

Chittenden, F. H. 1891. Notes on the food habits of some species of Chrysomelidae. Proc. Entomol. Soc. Wash. 2: 261-267.

Chittenden, F. H. 1897. The bean leaf beetle. U.S. Dep. Agric. Div. Entomol. Bull. 9: 64-71.

Chittenden, F. H. 1898. Insects injurious to beans and peas. U.S. Dep. Agric. Yearb. Agric. 1889: 233-260.

Davis, J. J. 1950. Insects of Indiana for 1950. Proc. Indiana Acad. Sci. 60: 178-182.

Eddy, C. O., and W. C. Nettles. 1930. The bean leaf beetle. Bull. S.C. Agric. Exp. Stn. Clemson Agric. Coll. 265.

Fribourg, C. E., and W. Perez. 1994. Bean pod mottle virus (BPMV) affecting Glycine max (L.) Merr. in the Peruvian jungle. Fitopatologia 29: 207-210.

Fulton, J. P., and H. A. Scott. 1974. Virus-vectoring efficiencies of two species of leaf-feeding beetles. Proc. Am. Phytopathol. Soc. 1: 159.

Gergerich, R. C., and H. A. Scott. 1988a. Evidence that virus translocation and virus infection of non-wounded cells are associated with transmissibility by leaf-feeding beetles. J. Gen. Virol. 69: 2935-2938.

Gergerich, R. C., and H. A. Scott. 1988b. The enzymatic function of ribonuclease determines plant virus transmission by leaf-feeding beetles. Phytopathology 78: 270-272.

Gergerich, R. C., H. A. Scott, and J. P. Fulton. 1986. Evidence that ribonuclease in beetle regurgitant determines the transmission of plant-viruses. J. Gen. Virol. 67: 367370 .

Ghabrial, S. A., D. E. Hershman, D. W. Johnson, and D. Yan. 1990. Distribution of bean pod mottle virus in soybeans in Kentucky. Plant Dis. 74: 132-134.

Giesler, L. J., S. A. Ghabrial, T. E. Hunt, and J. H. Hill. 2002. Bean pod mottle virus: a threat to US soybean production. Plant Dis. 86: 1280-1289.
Gu, H. C., A. J. Clark, P. B. de Sa, T. W. Pfeiffer, S. Tolin, and S. A. Ghabrial. 2002. Diversity among isolates of Bean pod mottle virus. Phytopathology 92: 446-452.

Helm, C. G., M. R. Jeffords, S. L. Post, and M. Kogan. 1983. Spring feeding activity of overwintered bean leaf beetles (Coleoptera: Chrysomelidae) on nonleguminous hosts. Environ. Entomol. 12: 321-322.

Henn, T. 1989. Analysis of bean leaf beetle feeding behavior in dual-choice preference testing of legumes. M.S. thesis, University of Illinois, Urbana, IL.

Higley, L. G., and D. J. Boethel, 1994. Handbook of soybean insect pests. Entomological Society of America, Lanham, MD.

Hill, J. H., N. C. Koval, J. M. Gaska, and C. R. Grau. 2007. Identification of field tolerance to bean pod mottle and soybean mosaic viruses in soybean. Crop Sci. 47: 212-218.

Hopkins, J. D., and A. J. Mueller. 1984. Effect of bean pod mottle virus on soybean yield. J. Econ. Entomol. 77: 943947.

Hopkins, J. D., and A. J. Mueller. 1983. Distribution of bean pod mottle virus in Arkansas soybean as related to the bean leaf beetle, Cerotoma trifurcata (Coleoptera: Chrysomelidae) population. Environ. Entomol. 12: 1564-1567.

Horn, H. L., L. D. Newsom, R. G. Carver, and R. L. Jensen. 1970. Effects of virus diseases on soybeans in Louisiana. La. Agric. 13: 12-15.

Horn, H. L., L. D. Newsom, R. G. Carver, and R. L. Jensen. 1973. Economic injury thresholds of bean pod mottle and tobacco ringspot virus infection of soybeans. Plant Dis. Rep 57: 811-813.

Koch, R. L., E. C. Burkness, and W. D. Hutchison. 2004. Confirmation of bean leaf beetle, Cerotoma trifurcata, feeding on cucurbits. J. Insect Sci. 4 (insectscience.org/ 4.5).

Koch, R. L., E. C. Burkness, W. D. Hutchison, and T. L. Rabaey. 2005. Efficacy of systemic insecticide seed treatments for protection of early-growth-stage snap beans from bean leaf beetle (Coleoptera: Chrysomelidae) foliar feeding. Crop Prot. 24: 734-742.

Kogan, M., G. P. Waldbauer, G. Boiteau, and C. Eastman. 1980. Sampling bean leaf beetles on soybean, pp. 201236. In M. Kogan and D. C. Herzog [eds.], Sampling methods in soybean entomology. Springer New York.

Krell, R. K., L. P. Pedigo, J. H. Hill, and M. E. Rice. 2003. Potential primary inoculum sources of Bean pod mottle virus in Iowa. Plant Dis. 87: 1416-1422.

Krell, R. K., L. P. Pedigo, J. H. Hill, and M. E. Rice. 2004. Bean leaf beetle (Coleoptera: Chrysomelidae) management for reduction of bean pod mottle virus. J. Econ. Entomol. 97: 192-202.

Krell, R. K., L. P. Pedigo, M. E. Rice, M. E. Westgate, and J. H. Hill. 2005. Using planting date to manage bean pod mottle virus in soybean. Crop Prot. 24: 909-914.

Lam, W.-K.F., and L. P. Pedigo. 2001. Effect of trichome density on soybean pod feeding by adult bean leaf beetles (Coleoptera: Chrysomelidae). J. Econ. Entomol. 94: $1459-1463$.

Lam, W.-K.F., L. P. Pedigo, and P. N. Hinz. 2001. Population dynamics of bean leaf beetles (Coleoptera: Chrysomelidae) in central Iowa. Environ. Entomol. 30: 562-567.

Lam, W.-K.F., L. P. Pedigo, and P. N. Hinz. 2002. Spatial distribution and sequential count plans for overwintering bean leaf beetles (Coleoptera: Chrysomelidae). J. Agric. Urban Entomol. 19: 73-84.

Lee, F. N., and H. J. Walters. 1970. A virus isolate from Desmodium related to bean pod mottle virus. Phytopathology 60: 585 . 
Lin, M. T., and J. H. Hill. 1983. Bean pod mottle virus: occurrence in Nebraska and seed transmission in soybeans. Plant Dis. 67: 230-233.

Mabry, T. R., H. A. Hobbs, T. A. Steinlage, B. B. Johnson, W. L. Pedersen, J. L. Spencer, E. Levine, S. A. Isard, L. L. Domier, and G. L. Hartman. 2003. Distribution of leaffeeding beetles and bean pod mottle virus (BPMV) in Illinois and transmission of BPMV in soybean. Plant Dis. 87: 1221-1225.

McConnell, W. R. 1915. A unique type of insect injury. J. Econ. Entomol. 8: 261-266.

Metcalf, R. L., and R. A. Metcalf. 1993. Destructive and useful insects: their habits and control, 5th ed. McGrawHill, New York.

Michelutti, R., J. C. Tu, W. A. Hunt, D. Gagnier, T. R. Anderson, and T. W. Welacky. 2002. First report of Bean pod mottle virus in soybean in Canada. Plant Dis. 86: 330.

Milbrath, G. M., M. R. McLaughlin, and R. M. Goodman. 1975. Identification of bean pod mottle virus from naturally infected soybeans in Illinois. Plant Dis. Rep 59: 982-983.

Moore, B. J., H. A. Scott, and H. J. Walters. 1969. Desmodium paniculatum, a perennial host of bean pod mottle virus in nature. Plant Dis. Rep. 53: 154-155.

Mueller, A. J., and A. W. Haddox. 1980. Observations on seasonal development of bean leaf beetle, Cerotoma trifurcata (Förster) and incidence of bean pod mottle virus in Arkansas soybean. J. Ga. Entomol. Soc. 15: 398-403.

Myhre, D. L., H. N. Pitre, M. Haridasan, and J. D. Hesketh. 1973. Effect of bean pod mottle virus on yield components and morphology of soybeans in relation to soil water regimes: a preliminary study. Plant Dis. Rep. 57: $1050-1054$.

Patel, V. C., and H. N. Pitre. 1971. Transmission of bean pod mottle virus to soybean by the striped blister beetle, Epicauta vittata. Plant Dis. Rep. 55: 628-629.

Pitre, H. N., V. C. Patel, and B. L. Keeling. 1979. Distribution of bean pod mottle disease on soybeans in Mississippi. Plant Dis. Rep 63: 419-423.

Quiniones, S. S., J. M. Dunleavy, and J. W. Fisher. 1971. Performance of three soybean varieties inoculated with soybean mosaic virus and bean pod mottle virus. Crop Sci. 11: $662-664$.

Ragsdale, D. W. 1984. Bean pod mottle virus and soybean yield: Effects of inoculation date and infection rate, p. 46. In R. Shibles [ed.], Program and abstracts World Soybean Research Conference III, 12-17 August 1984, Iowa State University, Ames, IA

SAS Institute. 2003. SAS/STAT user's guide, version 9.1 SAS Institute, Cary, NC.

Sikora, E. J., and J. F. Murphy. 2005. First report of Bean pod mottle virus in soybean in Alabama. Plant Dis. 89: 108.

Sims, S. R., P. G. Marrone, F. Gould, R. E. Stinner, and R. L. Rabb. 1984. Ecological determinants of bean leaf beetle, Cerotoma trifurcata (Förster) (Coleoptera: Chrysomelidae), size variation in North Carolina. Environ. Entomol. 13: $300-304$.

Stace-Smith, R. 1981. Comoviruses, pp. 171-195. In E Kurstak [ed.], Handbook of plant virus infections and comparative diagnosis, vol. 13. Elsevier/North-Holland Biomedical Press, New York.

Staines, C. L. 1986. An unusual food plant for adult Cerotoma trifurcata (Förster) (Coleoptera, Chrysomelidae). Proc. Entomol. Soc. Wash. 88: 392-392.

[USDA] U.S. Department of Agriculture. 2006. National Plant Data Center, The PLANTS Database. (http:/ / plants. usda.gov).

Waldbauer, G. P., and M. Kogan. 1976. Bean leaf beetle: phenological relationship with soybean in Illinois. Environ. Entomol. 5: 35-44.

Walters, H. J., and F. N. Lee. 1969. Transmission of bean pod mottle virus from Desmodium paniculatum to soybean by the bean leaf beetle. Plant Dis. Rep. 53: 411.

Werner, B. J., R. K. Krell, L. P. Pedigo, and J. H. Hill. 2003. The soybean leaf miner (Coleoptera: Chrysomelidae) as a vector of bean pod mottle virus. J. Kans. Entomol. Soc. 76: 643-644.

Zaumeyer, W. J., and H. R. Thomas. 1948. Pod mottle, a virus disease of beans. Phytopathology 38: 81-96.

Received 3 November 2006; accepted 7 February 2007. 
Corrections. In the article, "No-Choice Preference of Cerotoma trifurcata(Coleoptera: Chrysomelidae) to Potential Host Plants of Bean Pod Mottle Virus (Comoviridae) in lowa," by Jeffrey D. Bradshaw, Marlin E. Rice, and John H. Hill, published in the Journal of Economic Entomology (100: 808-814), the Confidence interval (95\%) columns for Table 1, p. 810, are all one decimal place off. The corrected Table 1 is below. The authors regret the error.

\begin{tabular}{|c|c|c|c|c|c|c|c|}
\hline \multirow{2}{*}{$\begin{array}{c}\text { Yr of exp } \\
\text { (duration) }\end{array}$} & \multirow{2}{*}{ Species } & \multirow{2}{*}{ Common name } & \multirow{2}{*}{$\begin{array}{c}\text { Mean area } \\
\text { consumed } \\
\left(\mathrm{mm}^{2}\right)^{a}\end{array}$} & \multicolumn{2}{|c|}{$\begin{array}{c}\text { Confidence } \\
\text { interval (95\%) }\end{array}$} & \multirow{2}{*}{$P$ value } & \multirow{2}{*}{$\begin{array}{c}\text { Fraction of } \\
\text { leaflets } \\
\text { with } \\
\text { herbivory } \\
\end{array}$} \\
\hline & & & & Lower & Upper & & \\
\hline \multirow[t]{14}{*}{$2004(24 \mathrm{~h})$} & Amorpha canescens Pursh & Lead plant & 0.12 & -0.7 & 0.9 & \multirow[t]{14}{*}{0.0002} & $1 / 6$ \\
\hline & Astragalus cicer $\mathrm{L}$. & Cicer milkvetch & 0.00 & -0.8 & 0.8 & & $0 / 6$ \\
\hline & Glycine $\max (\mathrm{L})$. & Soybean (Mark RR) & 2.29 & 1.5 & 3.1 & & $6 / 6$ \\
\hline & Lotus corniculatus $\mathrm{L}$. & Birdsfoot trefoil & $<0.01$ & -0.8 & 0.8 & & $1 / 6$ \\
\hline & Melilotus officinalis (L.) & Yellow sweet clover & 0.00 & -0.8 & 0.8 & & $0 / 6$ \\
\hline & Medicago sativa $\mathrm{L}$. & Alfalfa & $<0.01$ & -0.8 & 0.8 & & $1 / 6$ \\
\hline & Medicago officinalis (L.) & White sweet clover & 0.16 & -0.6 & 1.0 & & $1 / 6$ \\
\hline & Petalostemum purpureum (F.) & Purple prairie clover & 0.00 & -0.8 & 0.8 & & $0 / 6$ \\
\hline & Robinia pseudoacacia L. & Black locust & 0.02 & -0.8 & 0.8 & & $1 / 6$ \\
\hline & Securigera varia $(\mathrm{L})$. & Crown vetch & $<0.01$ & -0.8 & 0.8 & & $1 / 6$ \\
\hline & Trifolium hybridum $\mathrm{L}$. & Alsike clover & 0.01 & -0.8 & 0.8 & & $1 / 6$ \\
\hline & Trifolium pratense $\mathrm{L}$. & Red clover & 0.07 & -0.7 & 0.9 & & $3 / 6$ \\
\hline & Trifolium repens $\mathrm{L}$. & White clover & $<0.01$ & -0.6 & 1.0 & & $4 / 6$ \\
\hline & Trifolium ambiguum Bieberstein & Kura clover & 2.07 & 1.3 & 2.9 & & $3 / 6$ \\
\hline \multirow[t]{9}{*}{$2005(48 \mathrm{~h})$} & Amorpha canescens Pursh & Lead plant & 0.01 & -5.2 & 5.2 & \multirow[t]{9}{*}{0.0278} & $1 / 3$ \\
\hline & Glycine $\max (\mathrm{L})$. & Soybean (Mark RR) & 13.44 & 8.2 & 18.6 & & $3 / 3$ \\
\hline & Lotus corniculatus $\mathrm{L}$. & Birdsfoot trefoil & 1.57 & -3.6 & 6.8 & & $2 / 3$ \\
\hline & Melilotus officinalis (L.) & White sweet clover & 0.02 & -5.2 & 5.2 & & $1 / 3$ \\
\hline & Robinia pseudoacacia L. & Black locust & 0.52 & -4.7 & 5.7 & & $2 / 3$ \\
\hline & Trifolium alexandrinum $\mathrm{L}$. & Berseem clover & 0.21 & -5.0 & 5.4 & & $3 / 3$ \\
\hline & Trifolium ambiguum Bieberstein & Kura clover & 2.20 & -3.0 & 7.4 & & $3 / 3$ \\
\hline & Trifolium incarnatum $(\mathbf{F}$.) & Crimson clover & 1.21 & -4.0 & 6.4 & & $3 / 3$ \\
\hline & Trifolium pratense $\mathrm{L}$. & Red clover & 0.69 & -4.5 & 5.9 & & $2 / 3$ \\
\hline \multirow{3}{*}{$2006(60 \mathrm{~h})$} & Desmodium illinoense (L.) & Illinois ticktrefoil & 1.34 & -1.3 & 4.0 & \multirow{3}{*}{0.0001} & $10 / 10$ \\
\hline & Glycine $\max (\mathrm{L})$. & Soybean (Williams) & 9.42 & 6.7 & 12.1 & & $9 / 10$ \\
\hline & Lespedeza capitata (Michaux) & Roundhead lespedeza & 0.15 & -2.5 & 2.8 & & $3 / 10$ \\
\hline
\end{tabular}

\footnotetext{
${ }^{a}$ Mean area consumed is estimated from three (years 2004 and 2005) or one (year 2006) beetles per leaflet.
} 